\title{
MENENTUKAN TINGKAT IMUNISASI DAN PENGOBATAN OPTIMAL DARI MODEL EPIDEMIK PENYAKIT CAMPAK DENGAN METODE MINIMUM PONTRYAGIN
}

\author{
N. M. Ardilawati ${ }^{1}$, R. Ratianingsih ${ }^{2}$, dan A. I. Jaya ${ }^{3}$ \\ 1,2,3 Program Studi Matematika Jurusan Matematika FMIPA Universitas Tadulako \\ Jalan Soekarno-Hatta Km. 09 Tondo, Palu 94118, Indonesia. \\ 1Nimade.ardila@gmail.com, 2,3ratianingsih@yahoo.com
}

\begin{abstract}
Measles is a highly contagious infectious disease. The disease is caused by the measles virus. The symptoms are as follows acute exanthem acute, febrile, catarrhal mucous membranes and respiratory tract, disorders of the eye, and then followed by the eruption makulopapula red and ends with desquamation of the skin. Mathematical model that represent the spread of the shown that Measles is a endemic disease. The research studies an optimal controller of the Measles endemic model that aims to make the system no longer endemic. The controller is built by using the theory of Pontryagin minimum principle with immunization programs $\left(u_{1}\right)$ and treatment $\left(u_{2}\right)$. There are three control schemes of are examined, namely the controller of the immunization program, the controller the treatment program and the controller of combination of immunization and treatment programs. The simulation results show that the optimal controller is obtained by combination the immunization and the treatment with immunization rates of $90 \%$ and the rate of treatment programs are given sufficiently by $10 \%$. The simulation result also shows that the main controller of the spread of Measles disease is immunization program.
\end{abstract}

\section{Keywords $\quad$ : Endemic, Mathematical Model, Measles, Minimum Pontryagin}

\section{ABSTRAK}

Masalah penurunan kuantitas, kualitas maupun estetika ekosistem terumbu karang di Indonesia perlu diatasi. Campak adalah penyakit infeksi yang sangat menular. Penyakit tersebut disebabkan oleh virus campak. Adapun gejala-gejalanya adalah sebagai berikut eksantem akut, demam, kataral selaput lendir dan saluran pernapasan, ganguan pada mata, kemudian diikuti dengan erupsi makulopapula yang berwarna merah dan diakhiri dengan deskuamasi dari kulit. Model matematika yang mengkaji penyebaran menujukan bahwa penyakit tersebut bersifat endemik. Dalam penelitian ini dibangun pengontrol optimal dari model endemik penyakit Campak yang bertujuan untuk membuat sistem tidak endemik lagi. Pengontrol dibangun dengan mengunakan teori prinsip minimum Pontryagin dengan program imunisasi $\left(u_{1}\right)$ dan pengobatan $\left(u_{2}\right)$. Terdapat 3 skema pengontrolan yang dikaji, yaitu pengontrolan dengan program imunisasi, pengontrolan dengan program pengobatan dan pengontrolan dengan kombinasi program imunisasi dan pengobatan. Hasil simulasi memperlihatkan bahwa pengontrolan optimal diperoleh dengan kombinasi antara program imunisasi dan pengobatan dengan tingkat 
imunisasi sebesar $90 \%$ dan tingkat program pengobatannya cukup diberikan sebesar $10 \%$. Hasil simulasi juga memperlihatkan bahwa pengendalian utama penyebaran penyakit Campak adalah program pemberian imunisasi.

Kata Kunci $\quad$ : Endemik, Minimum Pontryagin, Model matematika, Penyakit Campak

\section{PENDAHULUAN}

\subsection{Latar Belakang}

Indonesia penyakit Campak (measles) adalah penyakit menular yang disebabkan karena infeksi virus Campak dari family paramyxovirus dan genus morbillivirus. Penyakit ini ditandai dengan demam, batuk, peradangan selaput ikat mata, danruam kulit. Adapun cara untuk mencegah meluasnya penyakit ini yaitu dengan melakukan program vaksinasi. Selain vaksinasi, dengan memberikan pengobatan (treatment) yang tepat bagi penderita juga mampu mengurangi jumlah kasus kesakitan dan kematian yang disebabkan oleh penyakit Campak. Program vaksinasi dilakukan dengan memberikan senyawa antigen yang berfungsi untuk meningkatkan imunitas tubuh terhadap virus atau penyakit sedangkan treatment yang dilakukan bersifat suportif dengan memberikan asupan gizi yang baik, asupan cairan yang cukup, suplemen nutrisi, serta pemberian antibiotik seperti vitamin A untuk mencegah terjadinya infeksi sekunder.

(http://repository.usu.ac.id/bitstream/123456789/20116/4/Chapter\%20II.pdf)

Dalam penelitian ini peneliti mengunakan model epidemi SEIR karena dalam pemodelan akan digunakan asumsi masa inkubasi. Dalam model ini populasi dibagi menjadi empat kelompok yaitu kelompok individu yang rentan (sehat tapi dapat terinfeksi) penyakit (Susceptible), kelompok individu yang terinfeksi penyakit tapi belum bisa menginfeksi (Exposed), kelompok individu yang terinfeksi dan dapat sembuh dari penyakit (Infected), dan kelompok individu yang sembuh dan kebal dari penyakit (Recovered). Model ini mengambarkan alur penyebaran penyakit dari kelompok Susceptible menjadi exposed melalui kontak langsung maupun perantara lain. Individu exposed menjadi infected ketika ketahanan tubuh menurun kemudian individu infected yang mampu bertahan hidup akan sembuh dan masuk pada kelompok recovered (Ulfa, Maesaroh, 2013). Peneltian lebih lanjut perlu dilakukan untuk membangun pengontrolan terhadap model matematika penyakit tersebut melalui prinsip minimum Pontryagin. 


\subsection{Rumusan Masalah}

Berdasarkan uraian diatas, maka pokok permasalahan yang dikemukakan dalam penelitian ini adalah bagaimana menentukan tingkat imunisasi dan tingkat pengobatan optimal dari model epidemik penyakit campak dengan metode minimum Pontryagin?

\subsection{Tujuan}

Berdasarkan perumusan masalah, penulisan ini bertujuan untuk menentukan dan mendapatkan tingkat imunisasi dan tingkat pengobatan optimal dari model epidemik penyakit Campak dengan metode minimum Pontryagin.

\subsection{Manfaat Penelitian}

Adapun manfaat yang dapat diberikan dari penelitian ini adalah :

1. Meningkatkan pemahaman tentang model epidemi penyakit Campak.

2. Membantu dalam meminimalisir penyebaran penyakit Campak.

3. Secara umum untuk mengembangkan ilmu matematika, khususnya pada bidang sistem dinamik yang diterapkan pada masalah-masalah lain.

4. Penelitian ini juga memiliki dampak yang positif bagi perkembangan multidisiplin ilmu di Indonesia, yaitu Matematika, Biologi, dan IImu Kesehatan Masyarakat.

\subsection{Asumsi Penelitian}

Asumsi yang digunakan dalam penelitian ini adalah:

1. Masa inkubasi penyakit Campak diperhatikan dalam model.

2. Sistem dalam keadaan terkontrol dan interaksi populasi tertentu.

3. Kontrol yang dapat diterima disimbolkan dengan $u_{1}$ dan $u_{2}$ untuk menentukan representasi dari program imunisasi dan pengobatan terhadap penyakit Campak.

\section{METODE PENELITIAN}

Penelitian dilakukan sesuai prosedur dibawah ini :

1. Memulai penelitian.

2. Mengkaji literatur untuk membangun pengontrol model epidemi penyakit Campak.

3. Mengkaji kestabilan model SEIR

4. Membangun pengontrol model epidemi penyakit Campak.

5. Menentukan penyelesaian optimal kontrol.

6. Melakukan simulasi untuk melahiat apakah sistem telah terkontrol. Jika sistem terkontrol maka dilanjutkan ke langkah selanjutnya, namun jika tidak maka kembali ke langkah (4).

7. Menyimpulkan hasil penelitian. 


\section{HASIL DAN PEMBAHASAN}

\subsection{Hasil penelitian}

Penelitian ini merupakan kajian terhadap model epidemik penyakit Campak yang dilakukan dengan menunjukan kajian pengontrol optimal dari model matematika penyakit tersebut. Model epidemik penyakit Campak dibangun sebagai berikut.

3.1.1. Kestabilan Model SEIR di titik kritis

$$
\begin{aligned}
& \frac{d S}{d t}=b-S I \beta-\mu . . \\
& \frac{d E}{d t}=S I \beta-\mu-\delta E \\
& \frac{d I}{d t}=\delta E-\mu-\gamma I . . \\
& \frac{d R}{d t}=\gamma I-\mu \ldots \ldots \ldots . . .
\end{aligned}
$$

Dari persamaan (1), (2), (3) dan (4) diperoleh nilai titik kritis yang memenuhi adalah

$(S, E, I, R)=$

$\left(\frac{(\mu+\gamma)(\mu+\delta)}{\delta \beta}, \frac{b \delta \beta-\mu^{3}+\mu^{2} \delta+\gamma \mu^{2}+\mu \delta \gamma}{\beta(\mu+\delta) \delta}, \frac{b \delta \beta-\mu^{3}+\mu^{2} \delta+\gamma \mu^{2}+\mu \delta \gamma}{\beta\left(\mu^{2}+\mu \delta+\gamma \mu+\delta \gamma\right)}, \frac{\gamma\left(b \delta \beta-\mu^{3}+\mu^{2} \delta+\gamma \mu^{2}+\mu \delta \gamma\right)}{\mu \beta\left(\mu^{2}+\mu \delta+\gamma \mu+\delta \gamma\right)}\right)$.

\subsubsection{Analisis Kestabilan Titik Kritis}

Matriks Jacobi $\left(J_{1}\right)$ digunakan untuk mencari nilai eigen yang diperoleh dengan membentuk

$$
\left.\operatorname{Det}\left(j_{1}-\lambda_{1} I\right)\right)=\left[\begin{array}{cccc}
-W+\left(\frac{b \delta \beta-\mu^{3}+\mu^{2} \delta+\gamma \mu^{2}+\mu \delta \gamma}{\beta\left(\mu^{2}+\mu \delta+\gamma \mu+\delta \gamma\right)}\right) \beta-\mu-\lambda_{1} & 0 & -\left(U+\frac{(\mu+\gamma)(\mu+\delta)}{\delta \beta}\right) \beta & 0 \\
W+\frac{b \delta \beta-\mu^{3}+\mu^{2} \delta+\gamma \mu^{2}+\mu \delta \gamma}{\beta\left(\mu^{2}+\mu \delta+\gamma \mu+\delta \gamma\right)} \beta & -(\delta+\mu)-\lambda_{2} & \beta\left(U+\frac{(\mu+\gamma)(\mu+\delta)}{\delta \beta}\right) & 0 \\
0 & \delta & -(\gamma+\mu)-\lambda_{3} & 0 \\
0 & 0 & \gamma & -\mu-\lambda_{4}
\end{array}\right]
$$

Dari hasil tersebut diperoleh $\lambda_{1}=\frac{b \delta \beta-\mu}{\mu^{2}+\mu \delta+\gamma \mu+\delta \gamma}, \quad \lambda_{2}=\delta-\mu, \lambda_{3}=\gamma-\mu$ dan $\lambda_{4}=-\mu$ Sehingga perlu diperiksa syarat-syarat kestabilannya.

\subsubsection{Membangun Pengontrol Model Epidemik Penyakit Campak}

Pada model epidemik penyakit Campak ada dua cara yang dapat dilakukan untuk mencegah penyebaran penyakit yaitu dengan cara meminimalisir banyaknya penderita yang terinfeksi penyakit melalui program Imunisasi untuk populasi rentan terinfeksi dan memberikan program pengobatan dengan memberikan vitamin A pada penderita penyakit Campak. Secara matematis, hal ini dilakukan dengan membangun pengontrol $u_{1}(t)$ untuk program pemberikan vaksin pada kelas populasi rentan Susceptible $(S)$, dan $u_{2}(t)$ untuk program pengobatan pada kelas populasi terinfeksi Infectious ( $I$ ). Pengontrol $u_{1}(t)$ dan $u_{2}(t)$ ditempatkan pada (1), (2), (3) dan (4). 
3.1.4. Penyelesaian Optimal Kontrol dengan Program Imunisasi pada Kelas Populasi Rentan Susceptible $(S)$

Hal pertama yang dilakukan untuk menyelesaikan optimal kontrol adalah dengan menentukan fungsi Hamiltonian:

$H=f(x, u, t)+\lambda g(x, u, t)$

dari persamaan Hamiltonian yang terbentuk akan diperoleh persamaan, co-state dan kondisi stasioner.

1. Persamaan co-state

$$
\begin{aligned}
& \left.\dot{\lambda_{1}}=-\frac{\partial H}{\partial S}=-A_{2} S-\lambda_{1}\left(-u_{1} I \beta-\mu\right)-\lambda_{2}\left(u_{1}\right) I \beta\right) \\
& \dot{\lambda_{2}}=-\frac{\partial H}{\partial E}=-\lambda_{2}(-\mu-\delta)-\lambda_{3}(\delta) \\
& \dot{\lambda_{3}}=-\frac{\partial H}{\partial I}=\lambda_{1}(u S \beta)-\lambda_{2}(u S \beta)-\lambda_{3}(-\mu-\delta)-\lambda_{4} \cdot \gamma \\
& \dot{\lambda_{4}}=-\frac{\partial H}{\partial R}=\lambda_{4}(\mu)
\end{aligned}
$$

2. Kondisi Stasioner

$\frac{\partial H}{\partial u_{1}}=0$, dengan kondisi batas $0,1 \leq u \leq 0.9$

\section{Simulasi}

Untuk mendapatkan simulasi berupa kurva dibutuhkan nilai $b=47,204, \beta=$ $0,315, \delta=0,062, \gamma=0,062, \mu=0.403, S=47204, E=315, I=62$ dan $R=62$.

Sumber : UPT Sudartin Tahun 2010

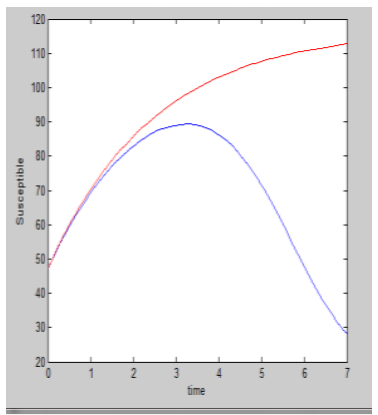

(a)

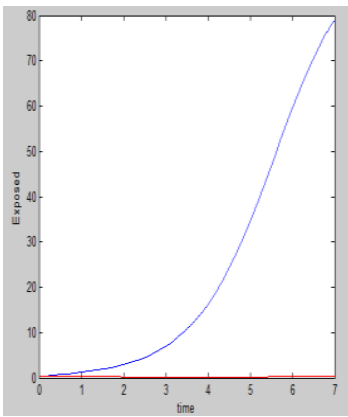

(b)

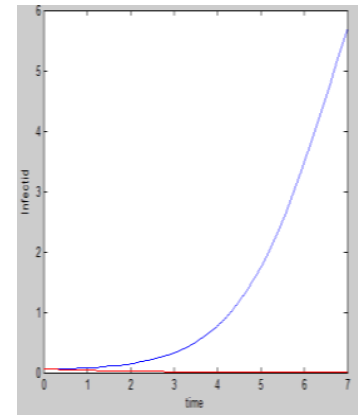

(c)

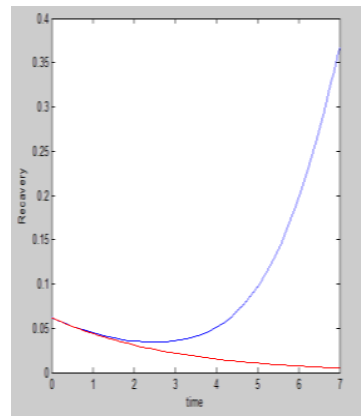

(d)

Gambar 1 : Kurva Optimal Kontrol dengan Program Imunisasi Pada Kelas Populasi Rentan Susceptible $(S)$

Gambar 1a menunjukkan populasi rentan (Susceptible) tanpa pengontrol yang mula-mula meningkat namun mengalami penurunan setelah 3 tahun. Hal ini disebabkan sebagian populasi Susceptible (S) tanpa pengontrol berpindah ke kelompok populasi Exposed (E). Tanpa pengontrol, populasi Exposed (E) akan meningkat seiring dengan bertambahnya waktu menuju ke total populasi $N$ seperti ditunjukkan pada gambar 1b. Sedangkan pada populasi Exposed $(E)$ dengan 
pengontrol tidak terjadi peningkatan populasi Exposed (E) dapat dilihat juga pada Gambar 1c yang merupakan Populasi Infectious (I) Terhadap Waktu. Tanpa pengontrol, populasi penderita penyakit Campak akan meningkat secara signifikan seiring dengan berjalannya waktu yakni berada di atas grafik populasi / dengan pengontrol terlihat sudah mendekati angka nol. Walaupun terlihat adanya kenaikan jumlah penderita namun jumlahnya sangat kecil. Pada gambar 1d Populasi Recovery $(R)$ terhadap waktu tanpa pengontrol akan meningkat seiring dengan bertambahnya waktu, sedangkan populasi Recovery $(R)$ dengan pengontrol akan menurun mendekati anggka nol dan terus bertambah seperti itu. Hal ini disebabkan oleh keberhasilan program pengontrolan yang mengakibatkan rendahnya populasi yang terinfeksi penyakit Campak.

\subsubsection{Penyelesaian Optimal Kontrol Pada Kelas Populasi Terinfeksi Infectious (I)}

Hal pertama yang dilakukan untuk menyelesaikan optimal kontrol adalah dengan menentukan fungsi Hamiltonian.

$H=f(x, u, t)+\lambda g(x, u, t)$

Dari persamaan Hamiltonia yang terbentuk akan diperoleh persamaan, co-state dan kondisi stasioner.

1. Persamaan co-state

$$
\begin{aligned}
& \dot{\lambda_{1}}=-\frac{\partial H}{\partial s}=-\lambda_{1}(-I \beta-\mu)-\lambda_{2}(I \beta) \\
& \dot{\lambda_{2}}=-\frac{\partial H}{\partial e}=-\lambda_{2}(-\mu-\delta)+\lambda_{3}(\delta) \\
& \dot{\lambda_{3}}=-\frac{\partial H}{\partial i}=-A_{2} I+\lambda_{1}(\mathrm{~S} \beta)-\lambda_{2}(\mathrm{~S} \beta)-\lambda_{3}\left(-\mu-\gamma\left(1-u_{2}\right)\right) \\
& -\lambda_{4}\left(1-u_{2}\right) \gamma \\
& \dot{\lambda}_{4}=-\frac{\partial H}{\partial r}=\lambda_{4}(\mu)
\end{aligned}
$$

2. Kondisi Stasioner

$\frac{\partial H}{\partial u_{2}}=0$, dengan kondisi batas $0,1 \leq u_{2} \leq 0.9$

\section{Simulasi}

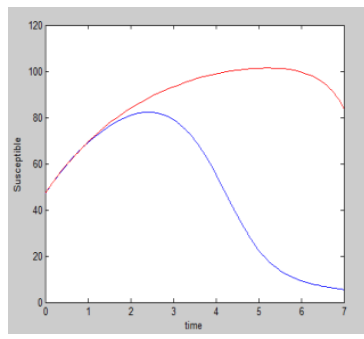

(a)

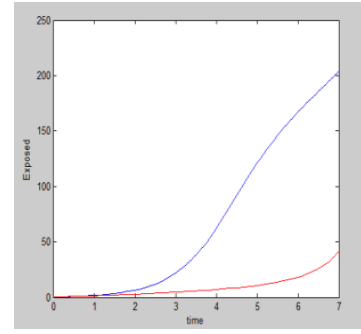

(b)

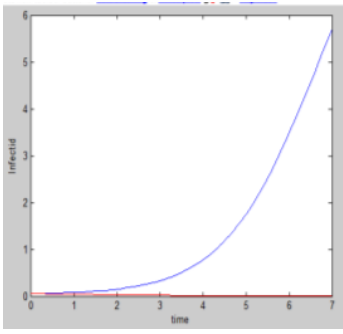

(c)

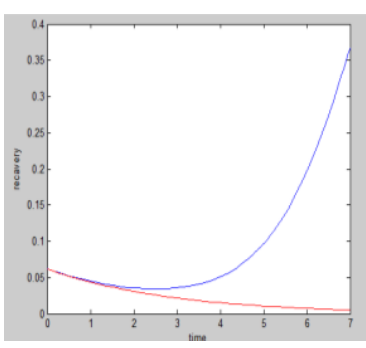

(d)

Gambar 2 : Kurva Optimal Kontrol pada Kelas Populasi Terinfeksi Infectious (I) 
Gambar 2a menunjukkan populasi rentan (Susceptible) baik tanpa pengontrol maupun dengan pengontrol yang mula-mula meningkat namun mengalami penurunan setelah 3 tahun Sebagian populasi Susceptible (S) dengan maupun tanpa pengontrol berpindah ke kelompok populasi Exposed (E). Hal ini memberikan arti bahwa dengan melakukan pengontrolan pada kelas populasi Infectious (I) tidak bisa menekan populasi rentan $S$ untuk tidak terjangkit penyakit Campak. Gambar 2b menunjukkan Populasi Exposed $(E)$ terhadap waktu dengan pengontrol akan meningkat seiring dengan bertambahnya waktu, peningkatan ini disebabkan oleh perpindahan sebagian populasi Exposed (E) menjadi Infectious (I). Pada Gambar 2c Populasi Infectious $(I)$ terhadap waktu tanpa pengontrol akan meningkat secara signifikan sedangkan populasi Infectious ( $I$ ) dengan pengontrol akan terlihat berada mendekati angka nol meskipun pada kelas populasi Exposed (E) terlihat ada peningkatan populasi Exposed (E) masuk ke kelas Infectious (I), namun dengan program pengobatan mampu menekan jumlah populasi Infectious (I). Gambar 2d menunjukkan Populasi Recovery $(R)$ Terhadap Waktu Tanpa pengontrol akan meningkat seiring dengan bertambahnya waktu, sedangkan populasi Recovery $(R)$ dengan pengontrol akan menurun mendekati anggka nol dan terus bertambah seperti itu. Hal ini disebabkan oleh keberhasilan program pengontrolan yang mengakibatkan rendahnya populasi yang terinfeksi penyakit Campak.

3.1.6. Penyelesaian Optimal Kontrol Pada Kelas Populasi Rentan Susceptible (S) dan Kelas Populasi Terinfeksi Infectious (I).

Menyelesaikan optimal kontrol adalah dengan menentukan fungsi Hamiltonian. $H=f(x, u, t)+\lambda g(x, u, t)$

Dari persamaan Hamiltonia yang terbentuk akan diperoleh persamaan, co-state dan kondisi stasioner.

1. Persamaan co-state

$$
\begin{aligned}
& \dot{\lambda_{1}}=-\frac{\partial H}{\partial s}=-A_{3} S-\lambda_{1}\left(-\left(u_{1}\right) I \beta-\mu\right)-\lambda_{2}\left(\left(u_{1}\right) I \beta\right) \\
& \dot{\lambda_{2}}=-\frac{\partial H}{\partial e}=-\lambda_{2}\left((-\mu-\delta)-\lambda_{3}(\delta)\right. \\
& \dot{\lambda_{3}}=-\frac{\partial H}{\partial i}=-A_{4} I+\lambda_{1}\left(u_{1}\right) S \beta-\lambda_{2}\left(u_{1}\right) S \beta-\lambda_{3}\left(-\mu-\gamma\left(1-u_{2}\right)\right) \\
& -\lambda_{4 \cdot} \cdot\left(1-u_{2}\right) \gamma \\
& \dot{\lambda_{4}}=-\frac{\partial H}{\partial r}=\lambda_{4}(\mu)
\end{aligned}
$$

2. Kondisi Stasioner

$\frac{\partial H}{\partial u_{1}}=0$, Dengan kondisi batas $0.1 \leq u_{1} \leq 0.9$

$\frac{\partial H}{\partial u_{2}}=0$, Dengan kondisi batas $0.1 \leq u_{2} \leq 0.9$ 


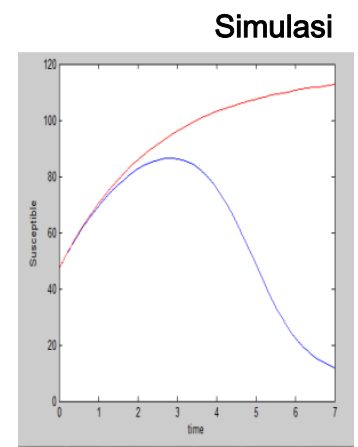

(a)

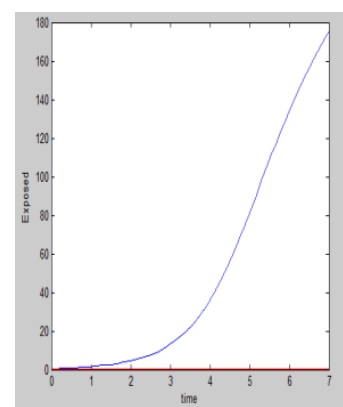

(b)

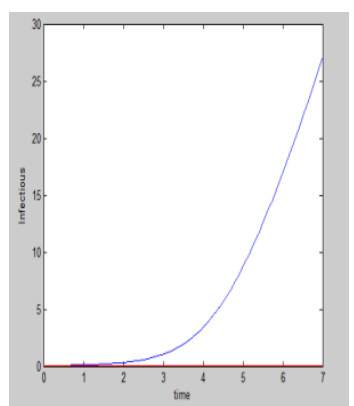

(c)

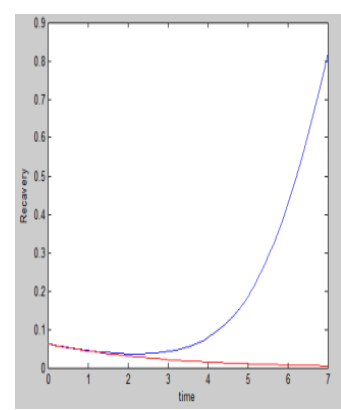

(d)

Gambar 3 : Kurva Optimal Kontrol pada Kelas Populasi Rentan Susceptible $(S)$ dan Kelas Populasi Terinfeksi Infectious (I)

Gambar 3a Populasi Populasi rentan Susceptible(S) Terhadap Waktu. Tanpa pengontrol, populasi rentan Susceptible $(S)$ akan naik, namun demikian banyaknya populasi Susceptible (S) tanpa pengontrol terlihat menurun setelah 3 tahun. Hal ini memberikan arti bahwa sebagian populasi Susceptible (S) tanpa pengontrol berpindah ke kelompok populasi Exposed (E). Kondisi ini tidak terjadi pada populasi Susceptible (S) dengan pengontrol. Gambar 3b. Populasi Exposed (E) Terhadap Waktu. Tanpa pengontrol, populasi Exposed $(E)$ akan meningkat seiring dengan bertambahnya waktu, peningkatan ini disebabkan oleh perpindahan sebagian populasi Susceptible $(S)$ menjadi Exposed $(E)$, sedangkan pada populasi Exposed $(E)$ dengan pengontrol berada mendekati angka nol. Gambar 3c Populasi Infectious (I) Terhadap Waktu. Tanpa pengontrol, populasi penderita penyakit Campak akan meningkat secara signifikan seiring dengan berjalannya waktu yakni berada di atas grafik populasi I dengan pengontrol yang terlihat mendekati angka nol. Walaupun terlihat adanya kenaikan jumlah penderita namun jumlahnya sangat kecil. Dan Gambar $3 \mathrm{~d}$ Populasi Recovery $(R)$ Terhadap Waktu Tanpa pengontrol, populasi Recovery $(R)$ akan meningkat seiring dengan bertambahnya waktu, sedangkan populasi Recovery $(R)$ dengan pengontrol akan menurun mendekati anggka nol dan terus bertambah seperti itu.

\subsection{Pembahasan}

Hasil yang diperoleh pada gambar 1a sampai 1d memperlihatkan bahwa pengontrolan pada kelas populasi rentan Susceptible $(S)$ mampu memaksimumkan pemberian vaksin pada jumlah populasi rentan Susceptible (S), dan menekan jumlah populasi Exposed (E) sehingga menurunkan populasi terinfeksi Infectious (I) hingga mendekati angka nol. Pada gambar 2a sampai $2 \mathrm{~d}$ memperlihatkan pengontrolan program pengobatan pada kelas Populasi terinfeksi 
Infectious ( $I$ ) dapat menurunkan populasi penderita penyakit Campak. Namun tidak mampu mengontrol julmah populasi Susceptible(S) berpindah ke kelas populasi Exposed (E) dan tidak mampu menekan peningkatan populasi Exposed (E) memasuki kelompok kelas yang terinfeksi Infectious (I). Pada gambar 3 a sampai 3 d memperlihatkan jika dilakukan pengontrolan pada kombinasi $S$ dan / dapat menurunkan populasi penderita penyakit Campak dan memaksimalkan jumlah populasi Susceptible(S) yang akan di beri vaksin, meskipun terlihat adanya peningkatan pada jumlah populasi Exposed (E) namun setelah memasiki kelas populasi Infectious (I) akan terlihat rendah. Hal tersebut memberikan arti bahwa program pengobatan mampu menekan populasi Exposed (E) untuk tidak terinfeksi enyakit Campak.

\section{KESIMPULAN}

Berdasarkan penelitian yang telah dilakukan dapat disimpulkan bahwa :

1. Pengontrolan optimal dari model epidemik penyakit Campak paling baik adalah dengan melakukan pengontrolah pasa $S$ dan $I$ yaitu dengan meninimalisir populasi yang terinfeksi penyakit campak dengan pemberian pengobatan dam memaksimalkan populasi penyakit campak yang akan di beri vaksin.

2. Pengontrolan optimal dari model epidemik penyakit Campak ditentukan dengan

a. Membangun performance index untuk meminimumkan jumlah penderita penyakit Campak.

b. Menyelesaikan persamaan optimal control yang dilakukan dengan menentukan fungsi Hamiltonian.

c. Fungsi Hamiltonian member persamaan state, co-state dan kondisi stasioner. Dengan menyelesaikan persamaan-persamaan tersebut, diperoleh optimal control untuk parameter $u_{1}$ dan $u_{2}$ sebagai berikut :

$$
\begin{aligned}
& u_{1}=\operatorname{maks}\left\{\min \left[\frac{\lambda_{1}(s e \beta)+\lambda_{2}(s e \beta)}{A_{1}}, 0.9\right] 0,1\right\} \\
& u_{2}=\operatorname{maks}\left\{\min \left[\frac{\lambda_{3}(\gamma i r)-(\text { yir })}{A_{2}}, 0.9\right] 0,1\right\}
\end{aligned}
$$

d. Mensubtitusi optimal kontrol yang diperoleh dalam keadaan state.

3. Pada model epidemik penyakit Campak dengan perinsip Metode Pontriagyagin dapat diketahui nilai parameter $u_{1}=\frac{\lambda_{1}(S I \beta)-\lambda_{2}(S I \beta)}{A_{1}}=0.9000$ dan $u_{2}=\frac{\lambda_{3}(\gamma I)+\lambda_{4}(\gamma I)}{A_{2}}=0.1000$ dari hasil tersebut memperlihatkan bahwa tingkat imunisasi harus diberikan secara maksimal sebesar $90 \%$ dan tingkat program pengobatannya cukup diberikan sebesar $10 \%$. Hal ini mamberi arti bahwa pengendali utama penyebaran penyakit Campak adalah program pemberian imunisasi. 


\section{DAFTAR PUSTAKA}

[1] Makalah Penyakit Campak.

http://repository.usu.ac.id/bitstream/123456789/20116/4/Chapter\%20II.pdf, diakses 6 September 2014.

[2] Dinas Kesehatan Provinsi Sulawesi Tengah. 2012. Profil Kesehatan Sulawesi Tengah Tahun. Palu. Sulawesi Tengah.

[3] Ekawati, Animah, 2010 Kestabilan Mode/ SEIR, Proceeding of the ISSN 2010.

[4] Fadila, Ana. 2013. Kontrol Optimal Pada Model epidemic SIR. Tugas Akhir S1 Jurusan Matematika, FMIPA. Universitas Brawijaya. Malang.

[5] Idayani Darsih. 2010. Kendali Optimal Pada Pengadaan Bahan MentahDengan Kebijakan Tepat Waktu, dan Penundaan. ITS. Surabaya.

[6] Tu, P. N. V. 1994. Dynamical system An Introduction with application in economics and biologi. Springer-Verlay. Germany.

[7]. Ulfa, Maesaroh. 2013. Model Matematika Untuk Kontrol Campak menggunakan Vaksinasi. Tugas Akhir S1 Jurusan Matematika UIN Sunan Kalijaga. Yogyakarta. 